Krizbai Diána Daniella ${ }^{1}$

\title{
Az új média veszélyei - az elmagányosodás, illetve radikalizálódás biztonságpolitikai aspektusból
}

\author{
The Threats of the New Media - Loneliness and \\ Radicalisation from a Security Policy Perspective
}

\begin{abstract}
Absztrakt
Az új média platformjainak népszerüsége töretlen, a társadalmi kapcsolatokáttevödnek a virtuális térbe. Társadalomkutatók rámutatnak, hogy egyre nehezebb az eröszakos tartalmak megfékezése, és a túlzásba vitt internetezés összefüggésben állhat a szociális kapcsolatok romlásával, amely súlyosabban jelentkezhet az egyébként is érzékenyebbeknél. Jelen tanulmány azt célozza meg, hogy biztonságpolitikai szempontból világítson rá az új média, s azzal összefüggésben az elmagányosodás, a radikalizálódó magányos elkövetök veszélyére.
\end{abstract}

Kulcsszavak: média, szociális kapcsolatok, elmagányosodás, radikalizáció

\begin{abstract}
The popularity of the new media's platforms is durable, the social relations are transferred into the virtual space. Meanwhile the sociologists explain that it is getting more and more difficult to stop the violent contents, and that too much surfing on the internet is in connection with the decline of social relations, which is more serious in case of sensitive people. This study aims to higlight from a security policy perspective the new media, and in connection with that, the danger of loneliness and lone attackers.
\end{abstract}

Keywords: media, social relations, loneliness, radicalisation

Magyar Távirati Iroda, újságíró - Hungarian News Agency, journalist, e-mail: dd.krizbai@gmail.com, ORCID: https://orcid. org/0000-0002-8153-2425 


\section{Bevezetés}

Elég csak körbenézni a közösségi terekben, szinte mindenki a telefonjába van merülve. A folyosókon már nem beszélgetnek az emberek, sőt már jellemzően nem is telefonálnak, hanem „megosztanak”, lájkolnak. A rendezvényeken, nyaralásokon, csoportos kirándulásokon is serényen fényképeznek azért, hogy a közösségi médiában megoszthassák „élményeiket”.

A közelmúltban maga Ferenc pápa is a következőkre figyelmeztetett

„[A]z internet lehetőséget kínál arra, hogy megkönnyítsük a másokkal való találkozást, de vezethet még mélyebb bezárkózáshoz is, és miként a pók hálója, csapdává válhat. Különösen a fiatalokat csábítja el az az illúzió, hogy a közösségi oldalak mindent képesek megadni kapcsolatok tekintetében, amire szükségük van. Ez végül ahhoz a veszélyes jelenséghez vezet, hogy e fiatalok internetes remetékké válnak, akik teljes egészében elidegenednek a társadalomtól. Ez a drámai dinamika pedig a társadalom kapcsolati-szervezeti törésében nyilvánul meg, egy olyan törésben, amelyet nem hagyhatunk figyelmen kívül".?

Mindeközben egyre több szakértő is felhívja a figyelmet, hogy a közösségi média kevéssé építi a közösséget, annál inkább rombolja a szociális kapcsolatokat. Jellemzően nagyobb figyelem irányul a telefonunkra, mint a köröttünk lévőkre. Megvan a veszélye, hogy bár a neten többszáz ismerőse, követője van valakinek, közben mégis elmagányosodik, hiszen valódi kapcsolatai nincsenek. Ha pedig ez a folyamat radikalizálódással társul, megvan a veszélye, hogy a talajt vesztő, szélsőségesekké váló egyének veszélyt jelentsenek önmagukra, illetve másokra.

Malajziában például egy tinédzser lány öngyilkos lett, miután az Instagramon szavazásra bocsátotta, megölje-e magát, vagy inkább éljen. Miután a többség az öngyilkosságra szavazott, megölte magát. ${ }^{3}$

De sok olyan esetet is hallottunk már, hogy számítógépeken, interneten „élő" emberek magányukban mások ellen fordultak, követtek el akár tömegmészárlásokat; legutóbb közvetítette is a merénylő. Biztonságpolitikai szempontból nem másodlagos, hogy közülük is sokan voltak, vannak viszont, akik digitális nyomokat hagytak maguk után. Például internetes naplójuk bejegyzései alapján, ha a konkrét tettre nem is, de következtetni lehetett arra, hogy valami baj van. Magyarországon például ennek - valamint az ámokfutást tervező fiú ismerősei jelzésének - köszönhetően sikerült megakadályozni tettében az egyetemista S. Ábelt, aki több ember lelövését tervezte.

Mint arra A magányos merénylök radikalizálódása címmel írt tanulmányában Farkas Johanna is felhívta a figyelmet, „a sérülékeny, a szélsőséges ideológiákra nyitott, pszichésen instabil fiatalok bármelyike tekinthető kockázatos személynek". ${ }^{4}$

Felhívta a figyelmet továbbá arra is, hogy „[A] szociális izoláció és az esetleges mentális zavarok oda vezethetnek, hogy az egyén képtelen egy csoporthoz csatlakozni;

\footnotetext{
Ferenc pápa üzenete a Tömegtájékoztatási eszközök 53. világnapjára. Vatikán, 2019. 01. 24. Elérhető: https://katolikus.hu/ cikk/ferenc-papa-uzenete-a-tomegtajekoztatas-53-vilagnapjara (A letöltés dátuma: 2020. 10. 29.)

Jamie Fullerton: Teenage girl kills herself, after Instagram poll' in Malaysia. The Guardian, 2019. 05. 15. Elérhető: www. theguardian.com/world/2019/may/15/teenage-girl-kills-herself-after-instagram-poll-in-malaysia (A letöltés dátuma: 2020. 10. 29.)

Farkas Johanna: A magányos merénylők radikalizálódása. Acta Humana, 4. (2016), 5. 17-31. 30.
} 
vagy a csoport utasítja el, mert számukra biztonsági kockázatot jelent. De az is előfordulhat, hogy az illető ideológiája túl radikális, esetleg a csoport szellemiségétől jelentősen eltér. Az is megtörténhet, hogy csatlakozik egy csoporthoz, és később dönt az önálló útról; akár stratégiai megfontolás is lehet az egyéni út, hiszen az egyén egyedül kevésbé tud lelepleződni, és ez számára fontosabb, mint a csoporthoz való tartozás élménye". 5

Az Európai Bizottság is felhívta a figyelmet: „[A] modern kommunikációs technológiák eddig soha nem látott mértékben biztosítanak hozzáférést információkhoz. A radikális eszmék terjesztői ezt kihasználva soha nem tapasztalt hatékonysággal alkalmaznak online eszközöket gyülöletkeltő üzeneteik terjesztésére. Emellett az internethasználók a szélsőséges tartalmakhoz a saját otthonukban is hozzáférhetnek. A radikális eszmék terjesztői könnyen kommunikálhatnak a radikalizálódás kockázatának kitett személyekkel". ${ }^{\circ}$

Jelen tanulmánnyal arra kívánok rávilágítani, hogy a biztonságpolitikai szektornak is figyelmet kell fordítania a fejlett technológiai eszközök miatt elmagányosodó emberekre. Azzal együtt, hogy figyelni kell az új média esetlegesen veszélyes, radikális, szélsőséges csatornáira, toborzó tevékenységére, szorosabb együttműködést kell kiépíteni a mentálhigiénés szakemberekkel, hogy sikerüljön még csírájában elfojtani a magányosodók radikalizálódását.

\section{Miért is kell vizsgálni a médiát mint veszélyforrást, különösen a fiatalok körében?}

Az Európai Bizottság egy közleményben hívta fel a figyelmet:

„[A]z emberek serdülőkor és a korai felnőttkor között a legfogékonyabbak, és az ebben az életszakaszban kialakult értékeket és attitűdöket életük nagy részén magukénak tudják. Ezért nem meglepő, hogy a radikális propaganda által leginkább veszélyeztetettek a serdülők és a fiatal felnőttek. Régebben a szülők, tanárok és közösségi vezetők hatékonyabban tudták ellenőrizni a szélsőséges tartalmakhoz való hozzáférést. Az új technológiák és a szélsőséges tartalmak elterjedése miatt azonban ma már más a helyzet".

Mint kiemelték: „[A] fiatalok gyakran egyedül interneteznek, amikor nincs velük senki, aki kritikusan szemlélné a káros tartalmakat. Ez fokozza annak veszélyét, hogy az üzenetek célba érnek és erőszakra késztetik a fiatalokat. A fiatalok az interneten a káros tartalmak mellett pozitív, a szélsőséges propagandával szembeni üzeneteket is találhatnak. Lépéseket kell tenni a fiatalok ösztönzése érdekében, hogy a passzív magatartás helyett gondolkodjanak kritikusan, és a szélsőséges nézeteket fogadják fenntartással és ki tudják szürni azokat".

Uo. 29 .

A Bizottság közleménye az európai parlamentnek, a tanácsnak, az európai gazdasági és szociális bizottságnak és a régiók bizottságának: a terrorista radikalizálódás és az erőszakos szélsőségek megelőzése: Az EU válaszának megerősítése. Brüsszel, 2014. 01. 15.

Uo.

Uo. 
Az NMHH 2017-ben 7-16 éves gyermekekkel és szüleikkel végzett médiakutatásából kiderül, hogy már a 7-8 éveseknek is 30\%-a, a 9-10 éveseknek pedig csaknem fele használ mobiltelefont. A 15-16 évesek 93\%-ának saját telefonja van. Ráadásul a telefonozók $88 \%$-a okostelefonnal rendelkezik, amellyel internetezni is lehet. A felmérésböl az is kiderül, hogy a gyermekek kevesebb mint felénél van valamiféle szülői kontroll a tekintetben, hogyan, mire használják telefonjukat. Utóbbi azért is fontos, mert a fiatalok több mint 60\%-a mobilját használja internetezésre.

A felmérésből kiderül az is, hogy míg a 7-8 éveseknek mindössze 3\%-a, a 15-16 éveseknek már $85 \%$-a rendelkezik saját profillal valamelyik közösségi oldalon. Köztük 99\% a Facebookot használja, csaknem 80\%-uk napi szinten. Véleményem szerint ez azért is fontos adat, mert egyértelmü, a magyarországi intézkedések, lépések fókuszában ezen közösségi oldalnak kell állnia. Elgondolkodtató adat, hogy a fiatalok mintegy kétharmada tesz fel magáról fényképet is. Riasztó viszont, hogy 6\%-uk pontos lakcímét is megadta az oldalon.

A felmérésben rákérdeztek továbbá arra is, hogy a gyermekek az elmúlt egy évben láttak-e gyülöletkeltésre alkalmas tartalmat, amely meghatározott csoportok ellen irányult (például származásuk, vallásuk alapján)? A válaszok alapján csaknem negyedük találkozott gyülöletkeltő tartalommal az elmúlt egy évben. ${ }^{9}$

\section{Mi az új média?}

Korábban A média felelőssége a terrorizmustól való félelemben című írásomban már igyekeztem felhívni a figyelmet arra, hogy a média, s valamennyi, különösen a 21. századi, tömegkommunikációs eszközök, mint például az okostelefonok, közösségi oldalak, tartalommegosztó portálok és internetes fórumok milyen nagy hatással képesek befolyásolni az embereket. Továbbá, hogy mindezen eszközök rossz kezekben - például bűnözők, terroristák eszközeiként - veszélyes fegyverek lehetnek az egyének és a társadalmak biztonsága szempontjából. Marshall McLuhan, aki sokat foglalkozott a média fejlődésével, úgy vélte, a kommunikáció elsődleges csatornája - legyen az szóbeli, írott vagy elektronikus - megváltoztatja annak módját, ahogyan észleljük a világot, és minden korban a domináns médium uralkodik az embereken. Az elektronikus média - vagyis a rádió, a televízió, internet - megjelenéseinek köszönhetően, McLuhan úgy vélte, egyfajta „globális falu” jött létre, amelyben bárkivel a világ szinte bármely pontján azonnal kapcsolata léphetünk, az azonnaliság korát éljük. A 20. században számos tömegkommunikációt kutató szakember feltételezte, hogy a nyomtatott és az elektronikus média jelentős mértékben befolyásolja az emberek véleményét, érzelmeit, sőt viselkedésüket is. „A tömegeket egy védtelen, viszonylag passzív birkanyájhoz hasonlították, amely könnyen áldozatul esik a manipulatív reklámhadjáratoknak, vagy

\footnotetext{
Médiahasználat-, médiafogyasztás-, médiaértés-kutatás 7-16 éves gyermekekkel és szüleikkel. A PSYMA Hungary Kft. kutatási jelentése a Nemzeti Média- és Hírközlési Hatóság részére, 2017.
} 
a jól kigondolt propagandának”.10 A média „korlátlan befolyásolás modelljét” vélték igazoltnak az 1930-as években a Göbbels-féle náci propaganda meggyőző erejében is."11

Bene Zoltánné Pusztai Virág Médiaelmélet című jegyzetében a következőképpen különböztette meg a hagyományos és az új média jellemzőit.

Napjainkban már "hagyományos” jelzővel illetik a következő médiumokat: „print” média, azaz nyomtatott média, „broadcast” média, azaz a rádió és tévéadások.

Mindkettö lineáris történetszerkezetben juttatta el a tartalmakat a felhasználókhoz, azaz elkezdenek mesélni, narrálni egy sztorit az elejétől, és abbahagyják a végén - mi pedig elolvassuk/megnézzük/meghallgatjuk. Nem jellemző rájuk az interaktivitás, a fogyasztó nem tud közvetlenül visszajelezni. Általuk egy szűk kör, az erre hivatottak (újságírók, műsorszerkesztők) közvetítenek információkat a tömeg felé, egy egyirányú folyamat során.

\section{Az „új” média felületei}

Az új média meghatározásának legegyszerübb, közérthetőbb módja, ha tisztázzuk annak felületeit. Napjainkban az új média felületeihez sorolható: a közösségiinternetmédia, a mobileszközök, okostelefonok, táblagépek alkalmazásai, továbbá az interaktív televíziók, videomegosztó-csatornák. ${ }^{12}$

„Az új média tartalmazza az új tartalmak szabályozásmentes, irreguláris, valós idejü létrehozásának lehetőségét. Tágabb értelemben: »Az újmédia bármely digitális eszközön, interaktív felhasználói visszacsatoláson, illetve kreatív részvételen alapuló, bármikor a mindenkori igény szerinti tartalomhoz való hozzáférést biztosító jelenség.« - írják Schivinski és Dąbrowski lengyel kutatók. Még tágabban értelmezve egyesek a fogalomba beleértik az olyan elemeket, mint a konvergencia, a globalizáció, a kibertér, a digitális gazdaság, az interaktivitás és a hálózati biztonsággal kapcsolatos kérdések."13

A tanulmány szerzője felhívta a figyelmet továbbá a következőkre:

„[S]okak mindennapi gondolkodását annyira uralják a közösségi hálók, hogy képtelenné válnak a valóság kínálta élmények élvezetére. Ahelyett, hogy egy-egy nyaralás, kirándulás, rendezvény stb. élményeit az adott pillanatban kiélveznék, egyfolytában fényképeznek és videóznak, arra készülve, hogy a képeket majd feltöltik a közösségi oldalra, megmutatva a világnak, hogy ők hol jártak, miben volt részük. Mindez hozzájárul ahhoz, hogy az emberek a valóságban egyre kevésbé találják a helyüket, így egyre több időt töltenek a közösségi hálón. Ott azonban valójában nem másokkal foglalkoznak, hanem saját magukkal. A felhasználók jellemzően jóval több időt töltenek a saját profiljuk formálásával, mint a mások dolgainak megnézegetésével. Sokak szerint a közösségek ily módon nem a társas kapcsolatokat, inkább az egót építik"14

10 Em Griffin: Bevezetés a kommunikációelméletbe. Budapest, Harmat, 2003. 318.

11 Krizbai Diána Daniella: A média felelössége a terrorizmustól való félelemben. Budapest, Nemzeti Közszolgálati Egyetem Hadtudományi és Honvédtisztképző Kar, 2013. 13-14.

12 Bene Zoltánné Pusztai Virág: Médiaelmélet. „Mentor(h)áló 2.0 Program”. Elérhető: www.jgypk.hu/mentorhalo/tananyag/ MediaelmeletV2/index.html (A letöltés dátuma: 2020. 08. 14.)

13 Uo.

14 Uo. 
„A professzionális hírmédia szervezetei az ezredforduló környékén szembesültek azzal, hogy a digitális hálózati médiában valóban adott a lehetőség, amit néhány évvel korábban mértékadó kutatók vagy iparági vezetők (Neogroponte, 1995; Gates, 1995) már felvázoltak, nevezetesen azt, hogy a felhasználók a különböző digitális platformokon, szoftverek segítségével a maguk preferenciái és előzetes értékítéletei szerint válogassanak a böségesen áramló hírek között. Ezzel mintegy saját digitális híranyagot (Negroponte találó elemzésében: »The Daily Me«) szerkeszthetnek maguknak, és kisvártatva kiderült, sokan élnek is ezzel a lehetőséggel.

Az ilyen jellegű felhasználói hírválogatás nem kívánt társadalmi következményeire hívta fel a figyelmet Chaffe és Metzger (2001) az ezredfordulón, rámutatva, hogy így a felhasználók bezárhatják magukat az önmagát megerősítő média gubójába (cocoon of self-reinforcing media), amelyben csak a világhálón talált hasonló gondolkodású társaikkal kommunikálnak". 15

(Láthatjuk, így müködik az a mesterséges intelligencia, amely ellát bennünket a fogyasztói érdeklődésünknek megfelelő hírekkel.)

Tari Annamária, a Z generáció könyv szerzője, ismert pszichoterapeuta egy fiataloknak szóló oldalon rámutatott, hogy bár vannak előnyei a közösségi oldalaknak, mint például a közösségi élmény, vagy az informálódás, több veszélye is van. Példaként említette a függőség veszélyét. „Az online létezés olyan erőteljes lehet egyeseknél, hogy egy 24 órás offline - közösségioldal-mentes - állapot előhívhatja a megvonási tüneteket. Ezek hasonlóak az alkohol vagy drog esetében tapasztaltakhoz: idegesség, szorongás, esetleg ingerlékenység."

Felhívta a figyelmet továbbá, a személyiségtorzulásra is. Mint kifejtette: „[F]ontos jellemzője az online felületnek az »én megmutatása«. Ez azonban egy olyan idealizált kép, amelyben a saját tulajdonságok, értékek olykor felülíródnak, mert mindenki az előnyös oldalát szeretné megmutatni a neten. Aki sokat van fent a közösségi oldalon, és mindenre figyel, olyan érzése lehet, hogy mindenki szép, okos és nagyon boldog, valamint mindig elfoglalt, sok ismerőse van. Ezek azonban nem minden esetben tükrözik a valóságot, és előfordulhat, hogy személyiségtorzulás alakul ki a felhasználónál. A zárkózottabbak még inkább bezárnak, mert ők nem tudnak olyan képeket kitenni, mint a többiek, mert nem tudnak posztolni világraszóló dolgokat, nem tudják kitenni, hol vannak éppen, azaz kilógnak a sorból, lemaradnak".

Külön kitért arra, hogy a közösségi oldalak milyen hatással vannak a közösségi kapcsolatokra. Azt írta: „a közösségi oldalaknak köszönhetően új barátságok születhetnek, de akár a meglévők is tönkremehetnek". Kiemelte továbbá, hogy "az információs kor abból a szempontból elég veszélyes, hogy a kamaszok a közösségi médiában a nárcisztikus, önimádó vonások túlreprezentáltságát látják és fogadják el természetesnek. Ennek az a következménye, hogy a természetes - korosztályos - agresszió mértéke megnőhet, egymással is keményebbek lehetnek a kamaszok"16

Az internet és a radikalizálódás közötti kapcsolatra a dark webet kutató Jamie Bartlett is rámutatott. Mint írta: „[A] radikalizálódás nem úgy néz ki, hogy az emberek

Gálik Mihály: A média átalakulása - A tömegmédiától a digitális hálózati médiáig. Vezetéstudomány, 49. (2018), 12. 58-66. 61.

16 Közösségi oldalak: ami elöny, az hátrány is lehet! 2014. Elérhető: www.kamaszpanasz.hu/hirek/lelek/5441/kozossegi_oldalak (A letöltés dátuma: 2020. 08. 14.) 
ülnek a nappaliban, és propagandavideókat néznek. Sokkal inkább úgy, hogy az internet különböző sarkaiban csoportokba verődnek, ahol a hasonló gondolkodású emberekkel kerülnek egy közösségbe. Ezek az emberek egymással osztják meg azokat a tartalmakat, amelyekkel mindannyian egyetértenek, így egymás üzeneteit visszhangozzák, és fokozatosan bezáródnak egy szúrőbuborékba, amely torzítja a világról kialakított képüket. Bartlett szerint ez az online radikalizálódás igazi trükkje: a buborékba zárt emberek egyre inkább felhergelik egymást, egyre frusztráltabbá és agresszívabbá válnak, így a vélemények egyre inkább polarizálódnak"17

\section{A magányos merénylök veszélyéröl}

Nyilvánvalóan nem lesz minden, az interneten vagy egyéb módon elmagányosodott ember merénylő. Kiszűrni a veszélyes egyéneket, pláne időben, nem könnyű. Ezért kiemelten fontos, hogy minél pontosabban meghatározzák, definiálják azokat a jeleket, speciális jellemvonásokat, amelyek mentén felkutathatók az esetlegesen erőszakos emberek, merénylők.

Farkas Johanna már említett tanulmányában kiemelte: „[A] magányos merénylők tevékenységének felderítése hatalmas kihívás, hiszen rendkívül nehéz kézzelfogható bizonyítékot találni az előkészületekre, ami alapján valószínűsíteni lehetne, hogy ki, mikor, hol, hogyan és miért szándékozik támadást végrehajtani. További nehezítő tényező, hogy nincs egységes profil, ezáltal nincs lehetőség arra sem, hogy az elhárító szervek a célcsoporthoz illeszkedő felderítési metodikát dolgozzanak ki.

A következő faktorok segítségével azonban speciális jellemvonásokat lehet felállítani:

- mentális zavarok,

- munkavállalás,

- párkapcsolati problémák,

- izoláció, erőszakos kommunikáció,

- szociális beilleszkedési zavar,

- intelligencia."18

A mentális zavarok kapcsán kiemelte például, hogy:

"Corner (2016) kimutatta, hogy a magányos merénylök körében az átlagpopulációhoz képest szignifikánsan több egyén (41-50\%) volt érintett valamilyen pszichopatológiában. Hasonló számadatokra jutott Spaaij (2010) is, aki ötből három magányos merénylőt diagnosztizált személyiségzavarral. Felhívta a figyelmet továbbá, hogy a magányos merénylők pszichés tünetei sokszor a diszfunkciók ellenére sem manifesztálódnak. Ezért a közvetlen környezet számára nem minden esetben nyilvánvalóak a személyiségtorzulások, bár az egyik vezető tünet (a szociális izoláció) tipikusan megjelenik az anamnézisben". ${ }^{19}$

17 Bolcsó Dániel: A radikálisoknak jobban fekszik az internet. 2015. 12. 16. Elérhető: https://index.hu/tech/2015/12/16/jamie_bartlett_radikalizmus_online_biztonsag/ (A letöltés dátuma: 2020. 08.14.)

18 Farkas i. m. (4. lj.) 23-24.

19 Uo. 24. 
A munkavállalásról azt írja, „a Gill (2014) által vizsgált 119 magányos merénylőből 40\% az elkövetés idején munkanélküli volt".

A párkapcsolati problémáknál azt jegyezte meg, hogy "Grunewald (2013) a magányos merénylők 37\%-ánál találta azt, hogy az elkövetés pillanatában egyedülállók voltak".

Az izoláció, erőszakos kommunikáció kapcsán arról írt, a „magányos merénylök általában szélsőséges ideológiákkal azonosulnak, az interperszonális kapcsolataikban gyakran izolálódnak".

A szociális beilleszkedési zavart kifejtve felidézte, „Jasparro (2010) kutatásai alapján 14 amerikai magányos merénylőből 9 - a barátok és a családtagok leírása alapján - szociális beilleszkedési problémával küzdött. Ez szorosan kapcsolódik az izolációhoz is. A magányos merénylők általában azért egyedül hajtják végre a cselekményeket, mert gyenge szociális képességeik, készségeik egyszerüen nem teszik lehetővé a mélyebb emberi kapcsolatok kialakítását és ápolását".

Az intelligenciáról azt írta: „Gill (2014) 119 magányos merénylő esetét vizsgálva azt tapasztalta, hogy a szocioökonómiai háttér is jól mutatja a potenciális merénylők behatárolásának problematikáját. A vizsgált személyek esetében $25 \%$ érettségivel, $54 \%$ pedig egyetemi végzettséggel rendelkezett, $8 \%$ pedig doktori címmel is."20 Mindez alapján arra jutottak, hogy minél intelligensebb az illető, annál inkább képes komplikált terveket konspirálni.

Az amerikai rendészeti szervek, beleértve az FBI-t és a nyomozóhatóságokat is, Alexander James Curtis, a felsőbbrendüséget hirdető magányos aktivista tevékenységéhez (1998) kötődően kezdték el alkalmazni a magányos merénylő („Operation Lone Wolf") kifejezést. ${ }^{21}$

Egy doktori disszertáció tervezetében a magányos merénylöket a következőképpen definiálták a „személyek általában egyedül radikalizálódnak, valamilyen szélsőséges eszme vagy csoport hatására, majd tervelnek ki/hajtanak végre erőszakos büncselekményeket. Felderítésük azért nehéz, mert általában nem tartanak fent kapcsolatot más szélsőséges személyekkel, illetve rejtett oldalakon teszik közzé gondolataikat, így nem kerülnek látókörbe” - írta a szerző, aki külön felhívta a figyelmet, „a magányos elkövetők esetében különösen célszerű az internetes tartalmak széles körü elemzése, mivel a szélsőséges gondolatok azonosítása révén felderíthetővé válhat egy tervezett merénylet".22

Kitért arra is, hogy „Hankiss Ágnes 2013-ban előadást tartott a terrorizmus elleni harcról, melyben elmondta, hogy a magányos farkas kifejezés az 1990-es évek végéröl származik, amikor két, a fehér faj felsőbbrendűségét hirdető radikális személy, Tom Metzger és Alex Curtis meghirdették a »szabadúszó terrorizmust«, és arra biztatták a híveiket, hogy taktikai megfontolásból egyedül és elszigetelten kövessenek el merényleteket. Ezek a személyek általában politikai indíttatásból követnek el

20 Uo.

21 Operation Lone Wolf. FBI. Elérhető: www.fbi.gov/sandiego/about-us/history/operation-lone-wolf (A letöltés dátuma: 2016. 07. 13.)

22 Szijártó Lívia: Alkalmazott pszichológiai módszerek a terrorizmus elleni harcban Szélsőséges csoportok és személyek internetes tevékenységének pszichológiai szempontú tartalomelemzése. Doktori értekezés (Tervezet). Budapest, NKE, 2019. 59. 
valamilyen eröszakos büncselekményt, és tevékenységük nem feltétlenül kötődik egy adott szélsőséges szervezethez". ${ }^{23}$

\section{A magányos merénylök típusai}

Egy nemzetközi elmélet szerint „megkülönböztethetünk káosz vezérelt és karrierista magányos elkövetőket. Az első típusba azok a merénylők tartoznak, akik olyan, egyedülálló támadást terveznek, ahol maximalizálni akarják mind a civil áldozatok számát, mind a sajtóérdeklődést. Közülük kerülnek ki az öngyilkos merénylök is. Ezzel szemben a karrierista terroristák rendszeres időközönként hajtanak végre kisebb hatásfokú merényleteket, hogy elérjék politikai céljaikat. Ezek a személyek magas önbecsüléssel rendelkeznek, hiszen úgy hiszik, hosszú távon képesek destruktív tevékenységet folytatni a hatóságok nyomozása mellett is.

A magányos elkövetési mód egyik közismert elmélete szerint a merénylöknek négy típusát lehet megkülönböztetni:

- »loner « - A fogalom magyar jelentése magányos ember. Ez a típus nem kötödik egy radikális szervezethez sem, azonban a merénylet megtervezésekor és kivitelezésekor szélsőséges ideológiával legitimálja a viselkedését. A »loner« általában passzív módon megfigyeli az általa szimpatikusnak vélt csoport internetes tevékenységét, propagandakiadványait, azonban kapcsolatba nem lép a tagokkal. Az ilyen típusnál nehéz megállapítani a valós elkötelezödést a szélsőséges ideológia irányába, mivel gyakori, hogy a háttérben valamilyen pszichológiai vagy szociális probléma áll (például elszegényedés, magány), amely fedésére szolgál a radikalizálódás és a merénylet megtervezése is.

- »lone wolf « - A kifejezés magyar jelentése magányos farkas. Ez a típus egyedül hajt végre terrorcselekményeket, látható külső nyomás nélkül, azonban bizonyíthatóan kapcsolatot tart fent legalább egy radikális csoporttal. A »lone wolf« föként az interneten lép kontaktusba a terrorszervezetekkel vagy más magányos elkövetővel.

- »lone wolf pack« - A kifejezés a magányos farkasok laza szerveződésére utal. Az ebbe a típusba tartozó személyek kis létszámú csoportban működnek, felhasználják a nagyobb szervezetek szélsőséges nézeteit, de nem tagozódnak be közéjük.

- »loner attacker« - A szó magyarul magányos támadót jelent. A típusba azok a merénylők tartoznak, akik habár egyedül követnek el merényleteket, bizonyíthatóan élvezik egy nagyobb terrorszervezet fizikai és anyagi támogatását. ${ }^{24}$

Az ezredfordulótól számítva megváltozott a radikális csoportok toborzásának metodikája: áttevődött a személyes útról a világhálóra. Nagyon könnyen elérhetőek a szélsőségesek által müködtetett felületek és csetszobák, a fórumok pedig elősegítik a személyek közötti interakciót és a szoros kapcsolattartást". ${ }^{25}$

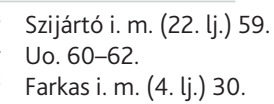


A közelmúltból a magányos merénylő példájaként kiemelhető Anders Behring Breivik szélsőjobboldali norvég terrorista. Az általa 2011. július 22-én elkövetett tömegmészárlásnak 77 halottja volt, ebböl heten Oslóban, 69-en Utoya szigetén, a Munkáspárt ifjúsági szervezetének nyári táborában vesztették életüket. Róla Bilkei Pál kriminálpszichológus egy internetes oldalnak azt mondta: „egy ember arca sok mindent elárul. Anders Behring Breivik arca egy rendezett ember benyomását kelti, aki tudatos, határozott személyiség". Szerinte a kettős terrortámadás vádlottja nem pszichopata, hanem fanatikus. Mint kiemelte: „a fanatikus emberre jellemző, hogy magányos. Ha vannak is barátai, akkor sem osztja meg velük a tervét feltétlenül. Minden idejét leköti a feladat végrehajtása" - mondta Bilkei. ${ }^{26}$

\section{Fellépés a magányos elkövetök ellen}

A már említett doktori disszertációban Szijártó Lívia felhívta a figyelmet, hogy Nicolas Cruz mellett - aki 2018 februárjában egy floridai iskolában 17 diákot és tanárt végzett ki fegyveres támadás során - Breivik is közzétette az interneten destruktív gondolatait, ami felveti azt a kérdést, hogy az internetes tevékenység monitorozása és elemzése segíthetne megakadályozni egy ilyen tragédiát. ${ }^{27}$

Az Európai Bizottság külön közleményt fogalmazott meg az Európai Parlamentnek, a tanácsnak, az európai gazdasági és szociális bizottságnak és a régiók bizottságának: a terrorista radikalizálódás és az erőszakos szélsőségek megelőzése: Az EU válaszának megerősítése címmel. Ebben felhívták a figyelmet, hogy az „online radikalizálódás miatti növekvő aggodalom és a nyíltan szélsőséges csoportok fokozottan érezhető európai jelenléte következtében a radikalizálódás egyre több tagállam számára jelent veszélyt. Az unióban a szélsőséges erőszakot eredményező radikalizálódás kockázata nő, így a tagállamok előnyére válna, ha az e kihívásokra adott hatékony válaszok érdekében fokoznák erőfeszítéseiket". ${ }^{28}$ Kiemelték, hogy a „radikalizálódás nincs tekintettel a nemzeti határokra. Többek között a csevegőszobák, a közösségi média és az egyéb online eszközök használata is nemzetközi vetülettel bír. A tagállamok gyakran hasonló fenyegetésekkel néznek szembe, így az uniós szintű fellépés hatékony lehet". ${ }^{29}$

Mint írták: „a terrorista csoportok és a szélsőségesek a műszaki fejlődést kihasználva újszerủ módon teremtenek kapcsolatot ellenséges érzületű fiatalokkal a közösségi oldalakat, az online videocsatornákat és a radikális csevegőszobákat igénybe véve. Propagandájukat szélesebb körben, gyorsabban és hatékonyabban terjesztik" - emelte ki a bizottság, amely arra is rámutatott, hogy „a hagyományos bünüldözési módszerek nem elégségesek ahhoz, hogy lépést tartsunk a radikalizálódás változó tendenciáival, így a radikalizálódás megelőzése és a jelenséggel szembeni fellépés érdekében szélesebb

26 Dezső András: A norvég mészáros nem pszichopata, hanem fanatikus. hvg.hu, 2011. 07. 25. Elérhető: https://hvg.hu/vilag/20110725_norveg_meszaros_lelke_breivik (A letöltés dátuma: 2020. 08. 14.)

27 Szijártó i. m. (22. lj.) 17.

28 A Bizottság közleménye az európai parlamentnek, a tanácsnak, az európai gazdasági és szociális bizottságnak és a régiók bizottságának: a terrorista radikalizálódás és az erőszakos szélsőségek megelőzése: Az EU válaszának megerősítése i. m. (6. lj.)

29 Uo. 
körü megközelítésre van szükség. A radikalizálódás tendenciáira reagáló széles körü megközelítésnek a társadalom egészét mozgósítania kell". ${ }^{30}$

Az Európai Bizottság - mint írták - „[M]ár most is támogatja az erőszakos szélsőségek megelőzését, illetve az ezekkel szembeni fellépést célzó tagállami erőfeszítéseket. A Bizottság 2011-ben hozta létre a radikalizálódást figyelő uniós információs központot (RAN), amely több mint 700 európai szakértőt és gyakorlati szakembert számlál. A RAN tevékenységei között szerepel a szakértői tapasztalatok gyűjtése, illetve több - köztük a helyi szereplők felelősségvállalása - témakörben az eszmecsere megkönnyítése a különböző szinteket képviselő szakértők részvételével megrendezett nemzetközi konferenciák szervezése révén".

„A RAN tapasztalatai rámutattak, hogy a nemzeti és helyi hatóságok előnyére válna, ha támogatnák a családokkal fenntartott intenzívebb kapcsolatokat, lehetővé téve hogy észleljék és fogadják fenntartással családtagjaik radikalizálódását, és lehetőség szerint megelőzzék azt. Nehéz körülmények között a tanácsadás, a segélyhívó szolgálatok és a helyi támogató hálózatok segítsége alapvető jelentőségü". ${ }^{31}$

A Bizottság közleményében rámutatott arra is, hogy a szélsőséges propagandával szembeni fellépés túlmutat az illegális tartalmak tiltásán, illetve eltávolításán. „Pozitív és finoman hangolt üzenetek kellően széles körü terjesztésére van szükség, amely a veszélyeztetett internethasználók számára könnyen hozzáférhető alternatívát kínál a terrorista propagandával szemben".

Az egész világra kiterjedő adatbázisok - a Global Terrorism Database és a RANDMIPT Terrorism Knowledge Base - alapján az 1968 és 2010 között 15 országot érintő 198 terrorakcióból 88-at magányos merénylők hajtottak végre. Míg 1970-ben 30 támadás történt, addig a 2000-es években ez a szám elérte a 73-at, ami 143\%-os növekedést jelent. ${ }^{32}$

Mint az előzőekben bemutattam, az új média felületeinek biztonságpoltikai vizsgálata több szempontból is indokolt. Sokan lehetnek, akik az internet miatt magányosodnak el. Vannak köztük olyanok, akik az internetes tartalmak hatására válnak erőszakossá, veszélyessé. Ezért úgy vélem, a biztonságpolitikai szakembereknek is ismerniük kell, milyen agresszív, szélsőséges tartalmak léteznek ebben a térben. A szélsőséges portálokat, üzemeltetőiket, szerzőiket, követőiket folyamatosan ellenőrizni kell.

Kiemelten foglalkozni kell azzal, hogy - különös tekintettel a fiatalokra - a közösségre, a társadalomra bomlasztólag hathat az új média töretlen népszerüsége. Mint azt bemutattam, ez a jelenség komplex probléma, egyaránt érinti a biztonságpolitikai, búnügyi szektort, pszichológusokat, szociológusokat, pedagógusokat, szülőket, gyermekeket egyaránt. Így a probléma elleni hatékony küzdelemhez az érintett szakterületek együttmüködésével, komplex válaszokat kell megfogalmazni, oly módon, hogy az valamennyi említett szakterület, továbbá a fiatalok egészséges szocializációja szempontjából is hasznos legyen.

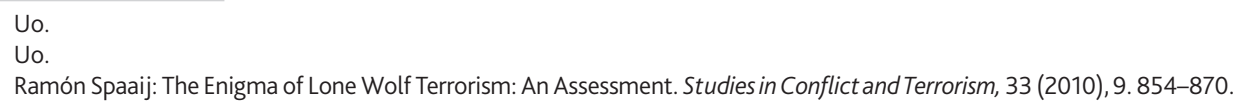




\section{Felhasznált irodalom}

Farkas Johanna: A magányos merénylők radikalizálódása. Acta Humana, 4. (2016), 5. 17-31. 30.

Gálik Mihály: A média átalakulása - A tömegmédiától a digitális hálózati médiáig. Vezetéstudomány, 49. (2018), 12. 58-66. DOI: https://doi.org/10.14267/ VEZTUD.2018.12.07

Griffin, Em: Bevezetés a kommunikációelméletbe. Budapest, Harmat, 2003.

Krizbai Diána Daniella: A média felelőssége a terrorizmustól való félelemben. Budapest, Nemzeti Közszolgálati Egyetem Hadtudományi és Honvédtisztképző Kar, 2013.

Médiahasználat-, médiafogyasztás-, médiaértés-kutatás 7-16 éves gyermekekkel és szüleikkel. A PSYMA Hungary Kft. kutatási jelentése a Nemzeti Média- és Hírközlési Hatóság részére, 2017.

Spaaij, Ramón: The Enigma of Lone Wolf Terrorism: An Assessment. Studies in Conflict and Terrorism, 33 (2010), 9. 854-870. 858. DOI: https://doi.org/10.1080 /1057610x.2010.501426

Szijártó Lívia: Alkalmazott pszichológiai módszerek a terrorizmus elleni harcban Szélsőséges csoportok és személyek internetes tevékenységének pszichológiai szempontú tartalomelemzése. Doktori értekezés (Tervezet). Budapest, NKE, 2019. 59.

\section{Internetes források}

Bene Zoltánné Pusztai Virág: Médiaelmélet. „Mentor(h)áló 2.0 Program”. Elérhető: www.jgypk.hu/mentorhalo/tananyag/MediaelmeletV2/index.html (A letöltés dátuma: 2020. 08. 14.)

Bolcsó Dániel: A radikálisoknak jobban fekszik az internet. 2015. 12. 16. Elérhető: https:// index.hu/tech/2015/12/16/jamie_bartlett_radikalizmus_online_biztonsag/ (A letöltés dátuma: 2020. 08. 14.)

Dezső András: A norvég mészáros nem pszichopata, hanem fanatikus. hvg.hu, 2011. 07. 25. Elérhető: https://hvg.hu/vilag/20110725_norveg_meszaros_lelke_ breivik (A letöltés dátuma: 2020. 08. 14.)

Ferenc pápa üzenete a Tömegtájékoztatási eszközök 53. világnapjára. Vatikán, 2019. 01. 24. Elérhető: https://katolikus.hu/cikk/ferenc-papa-uzenete-a-tomegtajekoztatasi-eszkozok-53-vilagnapjara (A letöltés dátuma: 2020. 08. 14.)

Operation Lone Wolf. FBI. Elérhető: www.fbi.gov/sandiego/about-us/history/operation-lone-wolf (A letöltés dátuma: 2016. 07. 13.)

Fullerton, Jamie: Teenage girl kills herself, after Instagram poll' in Malaysia. The Guardian, 2019. 05. 15. Elérhető: www.theguardian.com/world/2019/may/15/teenage-girlkills-herself-after-instagram-poll-in-malaysia (A letöltés dátuma: 2020. 08. 14.) Közösségi oldalak: ami előny, az hátrány is lehet! 2014. Elérhető: www.kamaszpanasz. hu/hirek/lelek/5441/kozossegi_oldalak (A letöltés dátuma: 2020. 08. 14.) 


\section{Jogi forrás}

A Bizottság közleménye az európai parlamentnek, a tanácsnak, az európai gazdasági és szociális bizottságnak és a régiók bizottságának: a terrorista radikalizálódás és az erőszakos szélsőségek megelőzése: Az EU válaszának megerősítése. Brüsszel, 2014. 01. 15. 